\title{
Vascular Plants of North America North of Mexico
}

The Flora North America project (FNA) was recently revitalized by the Man and Biosphere Program (MAB) as a binational effort between the United States and Canada to produce a conventional flora of the vascular plants of North America north of Mexico using traditional methods. Initial funding for the proposed five-volume work is being provided by the National Park Service of the Department of the Interior. The MAB/ FNA Program Council plans to coordinate the research that will be necessary to produce a floristic publication of high scientific quality pertinent to national needs.

The Program Council has appointed an Editoral Subcommittee consisting of Dr. Reed C. Rollins, Chairman, Gray Herbarium of Harvard University; Dr. Howard S. Irwin of the New York Botanical Garden; and Dr. Roy L. Taylor of the University of British Columbia Botanical Garden. Dr. James L. Reveal of the University of Maryland has been appointed Editor. Their function will be to stimulate and coordinate the efforts of the botanical community in the writing of the flora. Toward this goal, the Editoral Subcommittee is currently working on a proposed format for the flora. Initial efforts will be toward the production of a volume treating the monocotyledonous plants, with a volume on the sympetalous dicotyledonous plants to follow next. The remaining three volumes will be worked on in the future.

Long-term funding for the flora project is being explored by the Program Council, chaired by Dr. Peter H. Raven of the Missouri Botanical Garden. It is hoped that the flora project will be completed by 1990 .

Individuals wishing additional information or interested in contributing to the project, and in particular treatments of the monocots and sympetalous dicots should write to Dr. James L. Reveal, Editor, MAB/FNA Project, Department of Botany, University of Maryland, College Park, MD 20742.

\section{SECONd InTERnational Congress of Systematic AND EVOLUTIONARY BIOLOGY}

The Second International Congress of Systematic and Evolutionary Biology (ICSEBII) will be held at The University of British Columbia, Vancouver, Canada, 17-24 July 1980.

The provisional list of symposium topics includes: Arctic refugia and the evolution of Arctic biota; origins and evolution of the north Pacific marine biota; evolution of reproductive strategies; evolutionary epigenetics; evolution of community structure; green algae and land plant origins; macromolecular mechanisms in evolution; allozymes and evolution; coevolution and foraging strategy; evolution of colonizing species; rare species and the maintenance of gene pools; paleobiology of the Pacific rim.

Sessions for contributed papers and for papers in specialized fields, taxonomic as well as methodological, will also be organized.

Those interested in receiving an information circular in the spring of 1979, should write to: Dr. G. G. E. Scudder, Department of Zoology, The University of British Columbia, Vancouver, B.C. V6T 1W5 Canada.

\section{ROBERT JOSEPH RODIN}

Bob Rodin, sustained by his strong Christian commitment, succumbed to cancer on June 27, 1978, after a courageous struggle of nearly four years. Born in Turlock on July 15, 1922, Rodin received an A.B. degree from the University of California, Berkeley, in 1943, and served with the U.S. Marines on Guam in 1944-45, where he made a large plant collection. In 1947-48 he filled the role of botanist for the University of California African Expedition under the direction of Charles L. Camp, and made important collections in South-West Africa (Namibia). It was this latter experience that led to his 


\section{$2 \mathrm{BHL}$ Biodiversity Heritage Library}

1979. "Vascular Plants of North America North of Mexico." Madroño; a West American journal of botany 26, 51-51.

View This Item Online: https://www.biodiversitylibrary.org/item/185361

Permalink: https://www.biodiversitylibrary.org/partpdf/170782

\section{Holding Institution}

Smithsonian Libraries

\section{Sponsored by}

Biodiversity Heritage Library

\section{Copyright \& Reuse}

Copyright Status: In Copyright. Digitized with the permission of the rights holder License: http://creativecommons.org/licenses/by-nc/3.0/ Rights: https://www.biodiversitylibrary.org/permissions/

This document was created from content at the Biodiversity Heritage Library, the world's largest open access digital library for biodiversity literature and archives. Visit BHL at https://www.biodiversitylibrary.org. 